\title{
Wear and Corrosion Behavior of Al-Si Matrix Composite Reinforced with Alumina
}

\author{
Khalid Abd El-Aziz • Dalia Saber • \\ Hossam El-Din M. Sallam
}

Received: 9 October 2014/Revised: 4 December 2014/ Accepted: 17 December 2014/Published online: 6 January 2015

(C) Springer International Publishing AG 2015

\begin{abstract}
Al}-\mathrm{Si}$ alloy matrix composites reinforced with different weight fractions of $\mathrm{Al}_{2} \mathrm{O}_{3}$ particles up to $25 \mathrm{wt} \%$ were fabricated by stir casting method. The effect of weight fraction of $\mathrm{Al}_{2} \mathrm{O}_{3}$ and heat treatment on the wear behavior of $\mathrm{Al}-\mathrm{Si}$ alloy and its composites was investigated. The results showed that wear resistance of the investigated composites was improved by heat treatment and $\mathrm{Al}_{2} \mathrm{O}_{3}$ particles addition. The effect of heat treatment on the corrosion behavior of composites compared with its matrix in $3.5 \% \mathrm{NaCl}$ at $600 \mathrm{rpm}$ using electrochemical potentiodynamic polarization test was also investigated. The corrosion resistance of the composites with 10,15 , and $20 \% \mathrm{Al}_{2} \mathrm{O}_{3}$ particles was higher than that of the matrix alloy. Heat treatment of $\mathrm{Al}-\mathrm{Si}$ alloy and its composites resulted in marked improvements in the corrosion resistance as compared with these materials in the as-cast condition.
\end{abstract}

Keywords Aluminum alloys - Aluminum composites · Wear · Polarization $\cdot$ Corrosion

\section{Introduction}

Metal matrix composites (MMCs) represent a new generation of engineering materials in which a strong ceramic reinforcement is incorporated into a metal matrix to improve its properties including specific strength, specific

K. A. El-Aziz · D. Saber · H. E.-D. M. Sallam ( $\bowtie)$

Materials Engineering Department, Zagazig University,

Zagazig 44519, Egypt

e-mail: hem_sallam@yahoo.com

H. E.-D. M. Sallam

Civil Engineering Department, Jazan University,

Jazan 82822-6694, Saudi Arabia stiffness, wear resistance, corrosion resistance, and high elastic modulus [1-3]. The performance of various components in aerospace industries is based primarily on their wear and friction characteristics [4]. Previous studies on sliding wear of $\mathrm{Al}_{2} \mathrm{O}_{3}$-reinforced composites in the as-cast and heat-treated conditions varied and are often contradicting [5-8]. Das et al. [9] concluded that composites after heat treatment possess superior wear properties as compared with those of composites and matrix alloy in the as-cast condition. $\mathrm{Li}$ and Tandon [10] found that the wear resistance of $\mathrm{Al}-\mathrm{Si}$ alloys reinforced with $20 \mathrm{vol} \% \mathrm{SiC}$ particles was not improved significantly as a result of the heat treatment. One of the main obstacles to use of MMCs is the influence of reinforcement on corrosion resistance. This is particularly important in aluminum alloy composites, where a protective oxide film imparts corrosion resistance. The addition of reinforcement could lead to further discontinuities in the protective layer, increasing the number of sites where corrosion can be initiated and rendering the composite liable to severe attack [11, 12]. The main causes of the corrosion in MMCs are reported as (1) galvanic coupling between the matrix and the reinforcement materials, (2) formation of an interfacial phase between the reinforcement and matrix, and (3) microstructural changes processing contaminants resulted from manufacture of the MMC $[13,14]$. The effect of reinforcement on corrosion behavior of composites is still unclear. Corrosion current density has been shown to increase or decrease or remain unaffected in the presence of reinforcements. In addition, reinforcements have been shown to increase or decrease or not to affect the open circuit potential (OCP) [15]. The effect of heat treatment has been found to be the very important parameter in determining the corrosion behavior of aluminum alloy composites. Kolman and Butt [16] and Sun et al. [17] 
studied corrosion characteristics of in situ $\mathrm{TiB}_{2}$ particulatereinforced $\mathrm{Al}-\mathrm{Si}$ alloy composite after heat treatment. They reported that the corrosion resistance of the composites decreased with increasing $\mathrm{TiB}_{2}$ content. Włodarczyk-Fligier et al. [18] investigated the effect of heat treatment of the reinforcing $\mathrm{Al}_{2} \mathrm{O}_{3}, \mathrm{Ti}(\mathrm{C}, \mathrm{N})$, and $\mathrm{BN}$ particles in the $\mathrm{EN} \mathrm{AW}-\mathrm{AlCu}_{4} \mathrm{Mg}_{1}(\mathrm{~A})$ aluminum alloy on the corrosion resistance in the $\mathrm{NaCl}$ water solution environment. They found noticeable improvement of heat treatment on the corrosion resistance of composite materials in $3 \% \mathrm{NaCl}$ solution. Therefore, the main objective of current study is to investigate the effect of weight fraction of $\mathrm{Al}_{2} \mathrm{O}_{3}$ and heat treatment on corrosion behavior of $\mathrm{Al}-\mathrm{Si}$ MMCs reinforced by $\mathrm{Al}_{2} \mathrm{O}_{3}$ particles. The effect of heat treatment on wear behavior of $\mathrm{Al}-\mathrm{Si}$ alloy and its composites with different weight fractions of $\mathrm{Al}_{2} \mathrm{O}_{3}$ was also investigated. The companion paper [19] deals with the hardness and corrosive wear behavior of the Al-Si alloy matrix composites reinforced by $0,10,15,20$, and $25 \mathrm{wt} \%$ of $\mathrm{Al}_{2} \mathrm{O}_{3}$ particles. The influence of applied load on wear rate of $\mathrm{Al}-\mathrm{Si}$ alloy matrix composites has been also investigated [19].

\section{Experimental Procedure}

In this study, Al-Si alloy matrix with a density of $2.68 \mathrm{~g} / \mathrm{cm}^{3}$ was used as the matrix, while $\mathrm{Al}_{2} \mathrm{O}_{3}$ particles with a density of $3.9 \mathrm{~g} / \mathrm{cm}^{3}$ and an average particles size of $75 \mu \mathrm{m}$ were used as the reinforcement. The chemical analysis of $\mathrm{Al}-\mathrm{Si}$ alloy matrix used in this investigation is $7.1 \% \mathrm{Si}, 0.3 \% \mathrm{Mg}$, $0.01 \% \mathrm{Mn}, 0.02 \% \mathrm{Cu}, 0.01 \% \mathrm{Ni}$. The MMCs with $0,10,15$, 20 , and 25 wt $\% \mathrm{Al}_{2} \mathrm{O}_{3}$ particles were fabricated. The $\mathrm{Al}_{2} \mathrm{O}_{3}$ particles-reinforced $\mathrm{Al}-\mathrm{Si}$ MMCs have been produced by using stir casting method. The composites were shaped in the form of cylinder of $10 \mathrm{~mm}$ diameter, and height of $100 \mathrm{~mm}$. $\mathrm{Al}-\mathrm{Si}$ alloy was charged into the crucible and heated to about $750{ }^{\circ} \mathrm{C} . \mathrm{Al}_{2} \mathrm{O}_{3}$ particles were added to the molten metal with a particle addition rate of $5 \mathrm{~g} / \mathrm{min}$. The melt was stirred at a stirring speed of 700 r.p.m. and a stirring time of 5 min after the completion of particle feeding. Wettability was improved by heating $\mathrm{Al}_{2} \mathrm{O}_{3}$ to $900{ }^{\circ} \mathrm{C}$ before their dispersion in the melt and addition of $1 \% \mathrm{Mg}$. The specimens were heat-treated in the following way: solution treatment at $540{ }^{\circ} \mathrm{C}$ for $8 \mathrm{~h}$, water quenching at $60{ }^{\circ} \mathrm{C}$, and isothermal aging at $155^{\circ} \mathrm{C}$. After the solution treatment and/or the aging treatment, the specimens were stored at all times in a freezer (when not in use) to prevent any natural aging [20].

Dry sliding wear test was carried out on a pin-on-disk apparatus. This test was performed under dry sliding conditions between the specimen and steel disk. The wear pin specimens were of a cylindrical shape having a diameter of $9 \mathrm{~mm}$ and a height of $15 \mathrm{~mm}$. Test specimens were roughly ground up to grade 800 abrasive paper, making sure that the wear surface of the specimens is in a full contact with the surface of the disk. Before testing, the wear pin was held in a steel holder in the machine. The sliding wear tests were performed against steel disk with $200 \mathrm{~mm}$ diameter at a constant sliding speed of $1 \mathrm{~m} / \mathrm{s}$ under the load of $40 \mathrm{~N}$. The sliding distance was varied from 300 to $1,200 \mathrm{~m}$. The wear track diameter was kept constant at $80 \mathrm{~mm}$ in all tests. The mass losses of the specimens were obtained by determining the masses of the specimens before and after wear tests. The sliding wear rate was calculated by converting the mass loss measurements to volume loss by using the respective densities [21].

In corrosion test, MMCs and Al-Si alloy were totally immersed in $3.5 \% \mathrm{NaCl}$ electrolyte for 28 days. Corrosion rates $(\mathrm{mm} /$ year) were calculated based on mass loss of the materials. The specimens were cut in a form of circular disks with a diameter of $10 \mathrm{~mm}$ and a thickness of $3 \mathrm{~mm}$. The specimens were prepared by grinding to 600 grit. The specimens were weighed before immersion experiments. Approximately $250 \mathrm{ml}$ of $3.5 \% \mathrm{NaCl}$ electrolyte was poured into the beaker, so that the specimens were completely immersed in the electrolyte. A total of 10 beakers were partially covered to keep the evaporation of electrolyte. After the test, the specimens were cleaned in $50 \mathrm{vol} \%$ nitric acid $\left(\mathrm{HNO}_{3}\right)$, dried, and then weighed [22]. In potentiodynamic test, the specimens were cut into a form of circular disks with a diameter of $10 \mathrm{~mm}$ and a thickness of $3 \mathrm{~mm}$. The specimens were mounted in special acrylic mounting and prepared by grinding up to 600 grit. Small hole was made on the mounting for electrical connection of specimens in corrosion cell. The experimental arrangement for corrosion test consists of a magnetic stirrer and corrosion cell that composed of test specimen, reference calomel electrode, and auxiliary graphite electrode, and all of them were immersed in glass cylinder containing $3.5 \% \mathrm{NaCl}$ electrolyte. The potentiodynamic corrosion test was carried out at $600 \mathrm{rpm}$. Electrochemical parameters were determined using Minslberg potentiostat/galvanostat modelPS6. The initial and final potential as well as the scanning rate are adjusted; the output of each run consists of a polarization curve through which the corrosion parameters can be determined using a software package supplied by the manufacture using Tafel extrapolation technique.

\section{Results and Discussion}

\subsection{Microstructure}

Optical micrographs of the Al-7 \% Si alloy and 10, 15, and $25 \mathrm{wt} \% \quad \mathrm{Al}_{2} \mathrm{O}_{3}$ particle-reinforced composites, fabricated under the optimum production conditions, are shown in Fig. 1. The most important factor in the fabrication of MMCs 

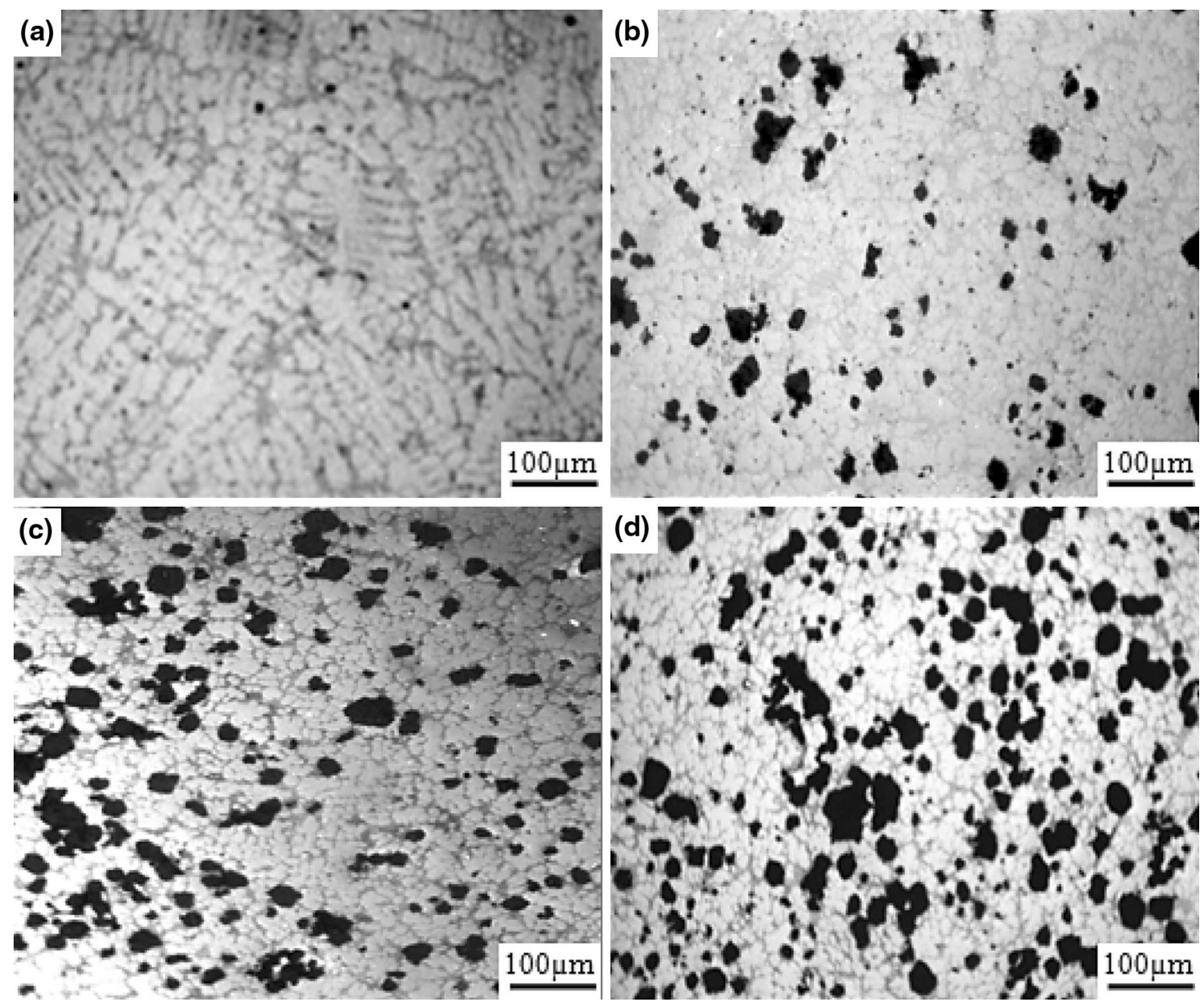

Fig. 1 Optical micrographs show the microstructure of the $\mathrm{Al}-\mathrm{Si} \mathrm{MMCs}$ with; a $0 \% \mathrm{Al}_{2} \mathrm{O}_{3}, \mathbf{b} 10 \% \mathrm{Al}_{2} \mathrm{O}_{3}, \mathbf{c} 15 \% \mathrm{Al}_{2} \mathrm{O}_{3}$, and d $25 \% \mathrm{Al}_{2} \mathrm{O}_{3}$

is the uniform dispersion of the reinforcements. As shown in Fig. 1, uniform dispersion of the particles was approximately achieved, but some of these particles agglomerated by increasing $\mathrm{Al}_{2} \mathrm{O}_{3}$ particle. The optical micrographs of the composites also show particle clustering and agglomeration. The dark black regions may indicate $\mathrm{Al}_{2} \mathrm{O}_{3}$ particle or porosity. As a result, optical observations of the microstructures revealed that increasing $\mathrm{Al}_{2} \mathrm{O}_{3}$ particle led to agglomeration and segregation of the particles and porosity. The reason for the particle segregation may be as follows: the $\mathrm{Al}$ dendrites solidify first during solidification of the composite, and the particles are rejected by the solid-liquid interface and hence are segregated in the inter-dendritic region [3].

Figure 2 shows SEM micrographs of the $\mathrm{Al}-\mathrm{Si}$ alloy matrix and composite with $25 \mathrm{wt} \% \mathrm{Al}_{2} \mathrm{O}_{3}$ that were fabricated under the best production conditions as mentioned above in Sect. 2. As shown in Fig. 2a, uniform dispersion of the particles was approximately achieved. Microstructure of Al-Si alloy consists of primary $\alpha$-Al dendrites and inter-dendritic region of either eutectic Si-rich phase or shrinkage cavities as shown in Fig. 2b, c. There are no gaps between the hard particles and the matrix. Figure $2 \mathrm{~d}$ shows the interfacial region between the matrix and $\mathrm{Al}_{2} \mathrm{O}_{3}$ particles. There is no debonding between the $\mathrm{Al}_{2} \mathrm{O}_{3}$ particles and the $\mathrm{Al}-\mathrm{Si}$ matrix, and an interface may be formed as a result of interaction between $\mathrm{Al}_{2} \mathrm{O}_{3}$ particles and molten $\mathrm{Al}-\mathrm{Si}$ alloy during fabrication process, as shown in Fig. 2d. According to previous study by Daoud and Reif [20], the particulate/matrix interaction in the composites containing $\mathrm{Al}_{2} \mathrm{O}_{3}$ particulates and aluminum matrix containing $\mathrm{Mg}$ may be due to the formation of $\mathrm{Al}_{2} \mathrm{MgO}_{4}$ spinel or $\mathrm{MgO}$ at the interface. The formation of $\mathrm{MgAl}_{2} \mathrm{O}_{4}$ spinel or $\mathrm{MgO}$ is possible from any of the following reactions:

$$
\begin{gathered}
\mathrm{MgO}+\mathrm{Al}_{2} \mathrm{O}_{3} \rightarrow \mathrm{MgAl}_{2} \mathrm{O}_{4} \Delta G=-7.69 \mathrm{kcal} / \mathrm{mol} \\
\mathrm{Mg}+4 / 3 \mathrm{Al}_{2} \mathrm{O}_{3} \rightarrow \mathrm{MgAl}_{2} \mathrm{O}_{4}+2 / 3 \mathrm{Al} \\
\Delta G=-19.17 \mathrm{kcal} / \mathrm{mol} \\
3 \mathrm{Mg}+\mathrm{Al}_{2} \mathrm{O}_{3} \rightarrow \mathrm{MgO}+2 \mathrm{Al} \\
\Delta G=-28.63 \mathrm{kcal} / \mathrm{mol}
\end{gathered}
$$



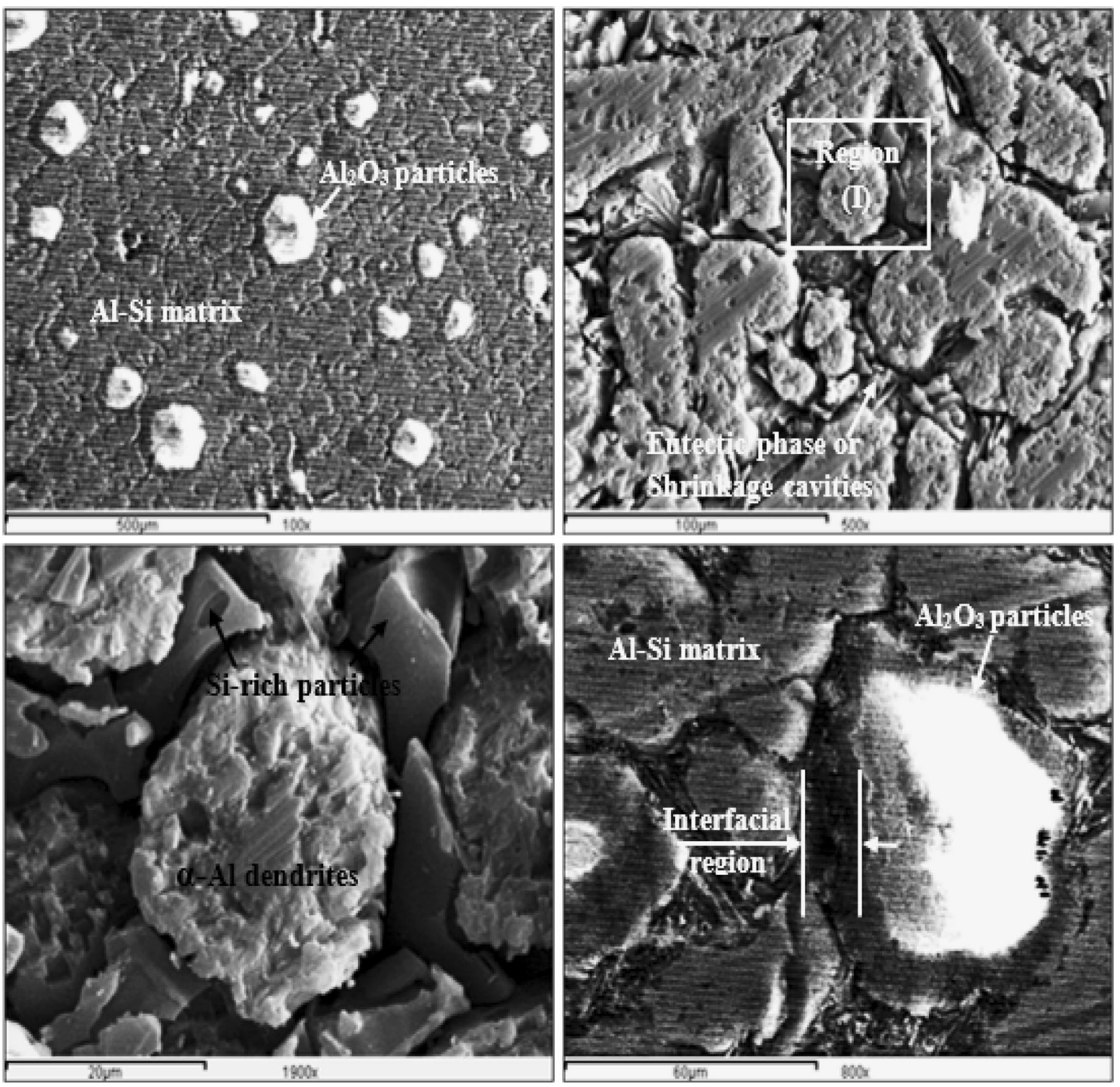

Fig. 2 SEM micrographs of the Al-Si alloy matrix composite with $25 \mathrm{wt} \% \mathrm{Al}_{2} \mathrm{O}_{3} ; \mathbf{a} \mathrm{Al}_{2} \mathrm{O}_{3}$ particles distribution, b dendritic structure of $\mathrm{Al}-\mathrm{Si}$ metal matrix, $\mathbf{c}$ details of region (I) in $\mathbf{b}$, and $\mathbf{d}$ interfacial region between matrix and reinforcement

The formation of either $\mathrm{MgO}$ or $\mathrm{MgAl}_{2} \mathrm{O}_{4}$ spinel depends on the $\mathrm{Mg}$ content in the melt. If the $\mathrm{Mg}$ content is lower than $7 \mathrm{wt} \%$, like in the present case, the formation of $\mathrm{MgAl}_{2} \mathrm{O}_{4}$ spinel is favored and is present mainly at the particulates/matrix interface [20]. Such an experimental observation indicates that the reaction given by Eq. 1, that describes the formation of $\mathrm{MgAl}_{2} \mathrm{O}_{4}$ spinel between two ceramics $\left(\mathrm{MgO}\right.$ and $\left.\mathrm{Al}_{2} \mathrm{O}_{3}\right)$, is unlikely due to the fact that solid-state reaction is kinetically very slow. Equation 2 describes the formation of the $\mathrm{MgAl}_{2} \mathrm{O}_{4}$ spinel as a result of direct reaction between the $\mathrm{Al}_{2} \mathrm{O}_{3}$ and $\mathrm{Mg}$ within the liquid matrix alloy. This is a possible mechanism for the formation of the spinel reaction product in the melt.

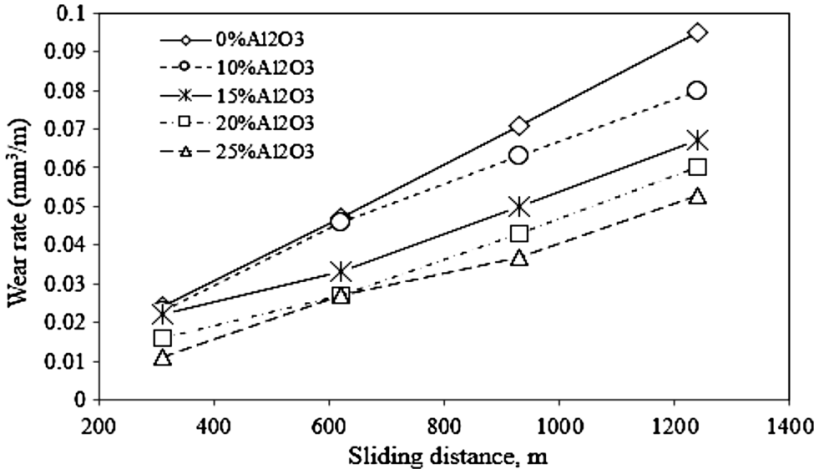

Fig. 3 Wear rate versus sliding wear distance of the Al-Si alloy matrix composites with different wt $\%$ of $\mathrm{Al}_{2} \mathrm{O}_{3}$ at load $=40 \mathrm{~N}$ 


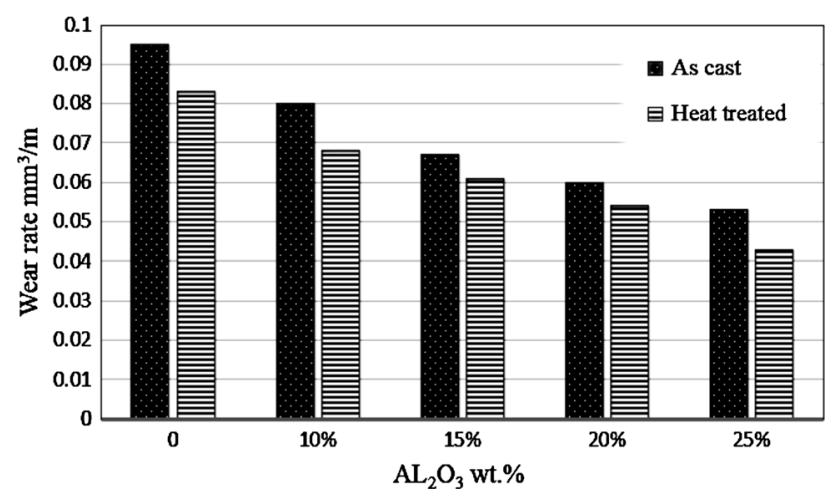

Fig. 4 Effect of heat treatment on the wear rate of Al-Si alloy matrix and its composites with $10,15,20$, and $25 \%$ wt $\%$ of $\mathrm{Al}_{2} \mathrm{O}_{3}$

\subsection{Effect of $\mathrm{Al}_{2} \mathrm{O}_{3}$ Particles and Heat Treatment} on Wear Behavior

Figure 3 shows the effect of sliding wear distance on the wear rate of Al-Si alloy as well as its composites with 10,
15,20 , and $25 \mathrm{wt} \%$ of $\mathrm{Al}_{2} \mathrm{O}_{3}$ at a load of $40 \mathrm{~N}$. It is clear that the wear resistance of the as-cast $\mathrm{Al}-\mathrm{Si}$ alloy and composites was decreased with increasing sliding distance, while the wear resistance of $\mathrm{Al}-\mathrm{Si}$ alloy matrix composites has increased with increasing wt $\%$ of $\mathrm{Al}_{2} \mathrm{O}_{3}$ particles. This is due to higher load-carrying capacity of the hard reinforcement $\mathrm{Al}_{2} \mathrm{O}_{3}$ particles, which limits the amount of plastic deformation of the matrix. These results were in agreement with several papers [23-25]. In Fig. 3, Al-Si alloy showed the highest wear rate $\left(0.095 \mathrm{~mm}^{3} / \mathrm{m}\right)$ at a sliding distance of $1,220 \mathrm{~m}$. While the composite with $25 \% \mathrm{Al}_{2} \mathrm{O}_{3}$ showed the lowest wear rate $\left(0.053 \mathrm{~mm}^{3} / \mathrm{m}\right)$ with wear resistance improving ratio of $69.2 \%$. The improvements in the wear resistance is because of the presence of hard particles, which increase the hardness of the material $[8,26]$. Ramachandra and Radhakrishna [26] described that in the initial stage of wear, the reinforcement particles act as load-carrying elements and as inhibitors against plastic deformation and adhesion of matrix
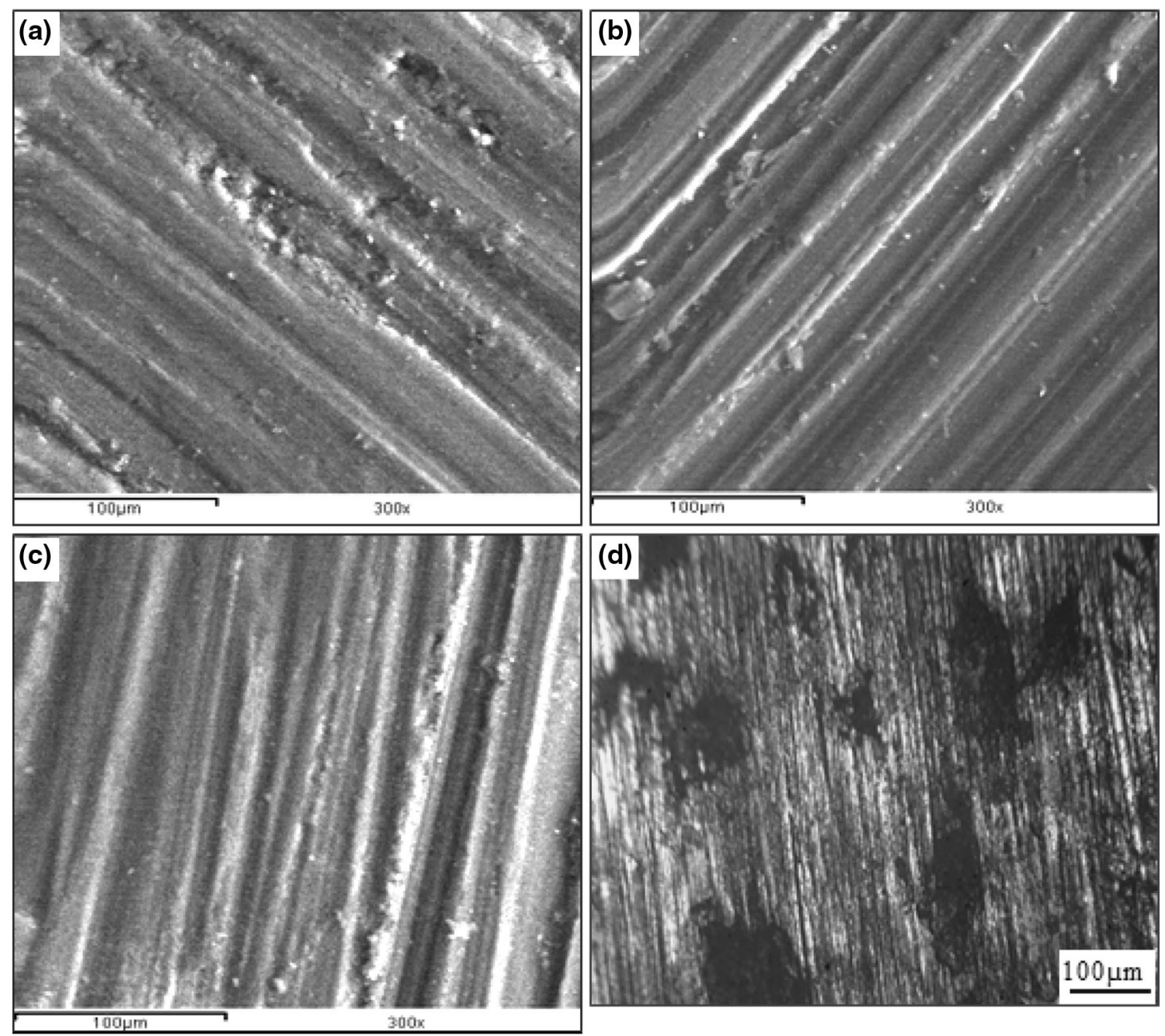

Fig. 5 SEM micrographs show the worn surfaces of $\mathrm{Al}-\mathrm{Si}$ alloy matrix and composites with a $0 \% \mathrm{Al}_{2} \mathrm{O}_{3}, \mathbf{b} 10 \% \mathrm{Al}_{2} \mathrm{O}_{3}$, and c $25 \% \mathrm{Al}_{2} \mathrm{O}_{3}$; d optical micrograph of the composite with $25 \% \mathrm{Al}_{2} \mathrm{O}_{3}$ 
material. In the later stages of wear, the worn particles are dislodged from their positions in the matrix and mixed with the wear debris. The wear debris containing matrix material, worn particles, and iron from the disk are pushed into the craters formed by dislodging of $\mathrm{Al}_{2} \mathrm{O}_{3}$ particles and act as load-bearing element.

Figure 4 shows the wear rates of the composites with different weight fractions of $\mathrm{Al}_{2} \mathrm{O}_{3}$ and in the as-cast and heat-treated conditions. It is clear that the wear rate of all heat-treated specimens is less than that of the specimens in the as-cast condition. The main reason for this improvement is clearly related to the hardness enhancement after the aging treatment [27-30]. The worn surfaces of tested specimens after wear test are shown in Fig. 5. The number of grooves, mostly parallel to the sliding direction, is an evident on all the worn pins. Such features are characteristics of abrasion, in which hard asperities of the steel counterface, or hard reinforced particles in between the contacting surfaces, plow or cut into the pin, causing wear by the removal of small fragments of material. Figure 5 also shows delamination of the surface after wear. Grooving and scratching appear more severe in the matrix

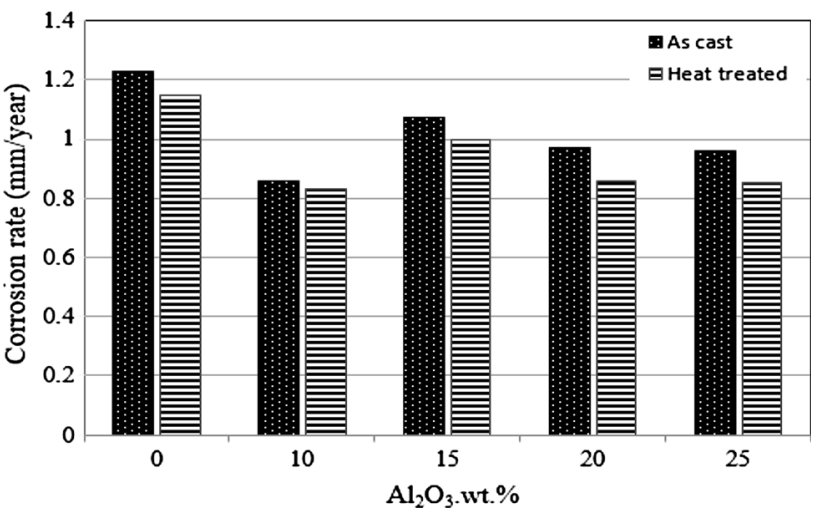

Fig. 6 Effect of heat treatment on the corrosion rate of the Al-Si alloy matrix and its composites with different wt\% of $\mathrm{Al}_{2} \mathrm{O}_{3}$

alloy as shown in Fig. 5a. On the other hand, grooves were less severe by the addition of $\mathrm{Al}_{2} \mathrm{O}_{3}$ particles as shown in Fig. 5b, c. Under the optical microscope, the dark surfaces are found to be covered extensively by a thin layer of fine particles as shown in Fig. 5d.

Table 1 Corrosion behavior of Al-Si alloy and composites in $3.5 \% \mathrm{NaCl}$ in the as-cast (AC) and heat-treated (T6) conditions

\begin{tabular}{|c|c|c|c|c|c|c|c|c|}
\hline \multirow[t]{2}{*}{ Specimens } & \multicolumn{2}{|c|}{$\begin{array}{l}\text { Corrosion rate }(\mathrm{mm} / \mathrm{year}) \text { in } \\
\text { immersion }\end{array}$} & \multicolumn{2}{|c|}{$\begin{array}{l}\text { Open circuit potential OCP } \\
(\mathrm{mV})\end{array}$} & \multicolumn{2}{|c|}{$\begin{array}{l}\text { Corrosion rate }(\mathrm{mm} / \\
\text { year) }\end{array}$} & \multicolumn{2}{|c|}{$\begin{array}{l}\text { Corrosion potential } E_{\text {cor }} \\
(\mathrm{mV})\end{array}$} \\
\hline & $\mathrm{AC}$ & T6 & $\mathrm{AC}$ & T6 & $\mathrm{AC}$ & T6 & $\mathrm{AC}$ & T6 \\
\hline Al-Si alloy & 1.23 & 1.15 & -724 & -876 & 0.0216 & 0.002 & -600 & -925 \\
\hline $\mathrm{MMC}-10 \% \quad \mathrm{Al}_{2} \mathrm{O}_{3}$ & 0.86 & 0.83 & -786 & -824 & 0.0051 & 0.0045 & -800 & -800 \\
\hline MMC-15 \% $\mathrm{Al}_{2} \mathrm{O}_{3}$ & 1.07 & 1 & -637 & -816 & 0.015 & 0.0011 & -650 & -900 \\
\hline $\mathrm{MMC}-20 \% \quad \mathrm{Al}_{2} \mathrm{O}_{3}$ & 0.97 & 0.86 & -657 & -860 & 0.0199 & 0.00113 & -600 & -950 \\
\hline $\mathrm{MMC}-25 \% \quad \mathrm{Al}_{2} \mathrm{O}_{3}$ & 0.96 & 0.85 & -788 & -817 & 0.0484 & 0.00131 & -650 & -875 \\
\hline
\end{tabular}

Fig. 7 Polarization curves for Al-Si alloy matrix and its composites with different wt $\%$ of $\mathrm{Al}_{2} \mathrm{O}_{3}$ particles tested in $3.5 \% \mathrm{NaCl}$

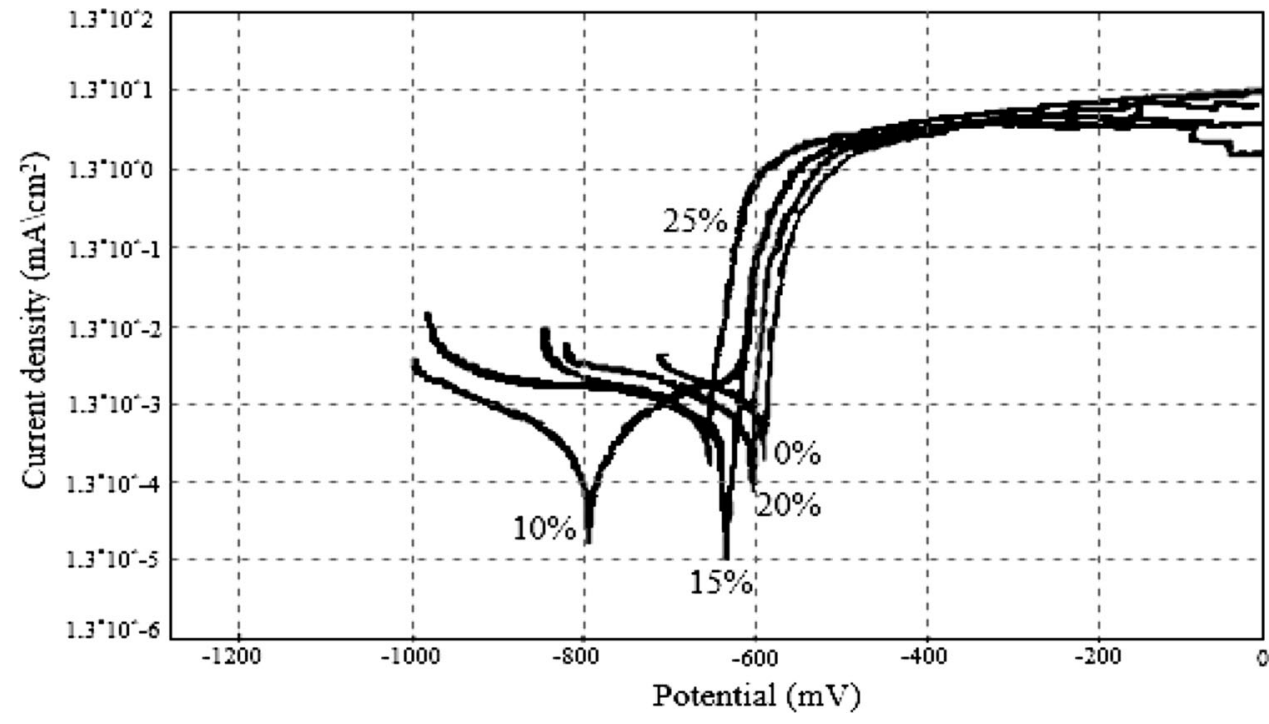




\subsection{Corrosion Behavior}

\subsubsection{Immersion Test}

In immersion experiment, MMCs and its matrix alloy were totally immersed in $3.5 \% \mathrm{NaCl}$ solution for 28 days. The corrosion rate (mm/year) for MMCs and its matrix alloy are summarized in Table 1. As shown in the Table, the MMC with $10 \mathrm{wt} \% \quad \mathrm{Al}_{2} \mathrm{O}_{3}$ recorded the lowest corrosion rate $(0.86 \mathrm{~mm} /$ year $)$. It can be also noted that more addition of $\mathrm{Al}_{2} \mathrm{O}_{3}$ particles increases the corrosion rate of composites with 15,20 , and $25 \mathrm{wt} \% \mathrm{Al}_{2} \mathrm{O}_{3}$, but it is still less than the corrosion rate of Al-Si alloy matrix (ranged from 82 to $95 \%$ of the corrosion rate of $\mathrm{Al}-\mathrm{Si}$ alloy matrix). This trend suggests that the introduction of $\mathrm{Al}_{2} \mathrm{O}_{3}$ particles to the Al-Si matrix improved the corrosion resistance of the matrix alloy. It is also clear that the corrosion resistance after heat treatment of composites and Al-Si alloy matrix is substantially greater than that in the as-cast condition as shown in Fig. 6. This improvement in the corrosion resistance of all MMCs may be due to a good connection of the matrix with the reinforcement particles. In addition, the $\mathrm{pH}$ value of $\mathrm{NaCl}$ solution is 7.5 , and it is observed from the $\mathrm{pH}$-potential-Pourbaix diagram of aluminum that aluminum passivates in the $\mathrm{pH}$ range of $4.0-8.0$ by the rapid formation of aluminum oxide film [31, 32]. Moreover, $\mathrm{Si}$ particles as well as $\mathrm{Al}_{2} \mathrm{O}_{3}$ particles have poor conductivity and cannot act as a cathode of corrosion reaction [16, 22, 33].

\subsubsection{Potentiodynamic Corrosion Test}

The polarization curves presented in Fig. 7 show the corrosion behavior of MMCs and its matrix alloy in the as-cast condition. In cathodic range, the current densities were nearly the same for all specimens. It can be noticed that MMCs with 15,20 , and $25 \% \mathrm{Al}_{2} \mathrm{O}_{3}$ and its matrix alloy showed anodic dissolution with no passive range. On the other hand, the MMC with $10 \mathrm{wt} \% \mathrm{Al}_{2} \mathrm{O}_{3}$ showed a passive range approximately $(\sim 100 \mathrm{mV})$. The results of immersed corrosion test and potentiodynamic corrosion test at $600 \mathrm{rpm}$ are listed in Table 1 . It is worth to note that there is no difference between the results of immersed corrosion test and those of potentiodynamic corrosion test under stagnant conditions. The $\mathrm{MMC}$ with $25 \mathrm{wt} \% \mathrm{Al}_{2} \mathrm{O}_{3}$ recorded the most negative OCP $(-788 \mathrm{mV})$, while the most noble was for the $\mathrm{MMC}$ with $15 \mathrm{wt} \% \mathrm{Al}_{2} \mathrm{O}_{3}$, as noted in Table 1. The corrosion rate of the matrix alloy was $0.0216 \mathrm{~mm} /$ year. The corrosion rate recorded remarkable decrease $\left(0.0051 \mathrm{~mm} /\right.$ year) for $\mathrm{MMC}$ with $10 \mathrm{wt} \% \mathrm{Al}_{2} \mathrm{O}_{3}$ followed by a gradual increase in the case of MMC with $15 \mathrm{wt} \% \mathrm{Al}_{2} \mathrm{O}_{3}(0.015 \mathrm{~mm} /$ year $)$. However, its value never (a)

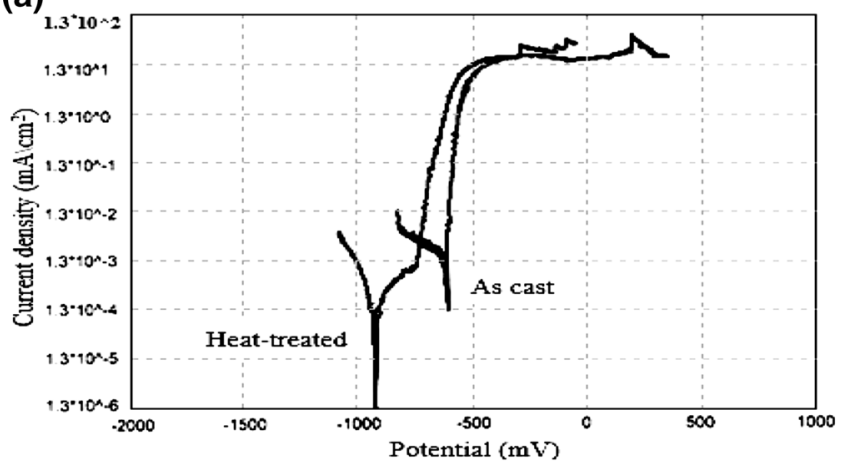

(b)

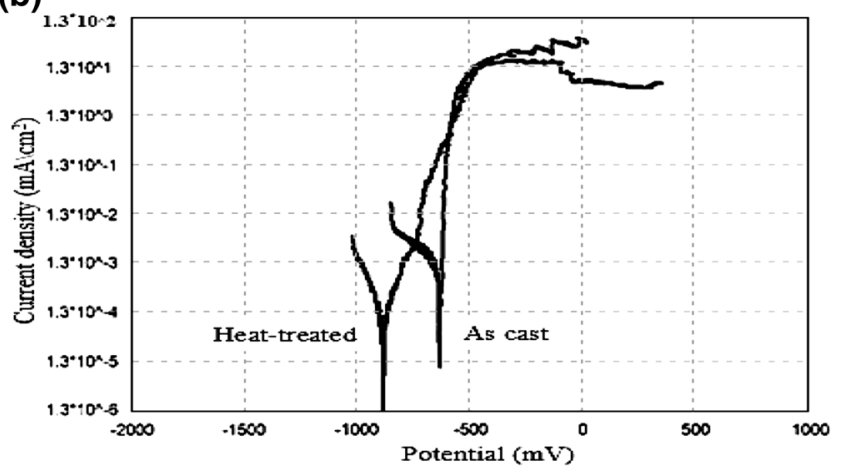

(c)

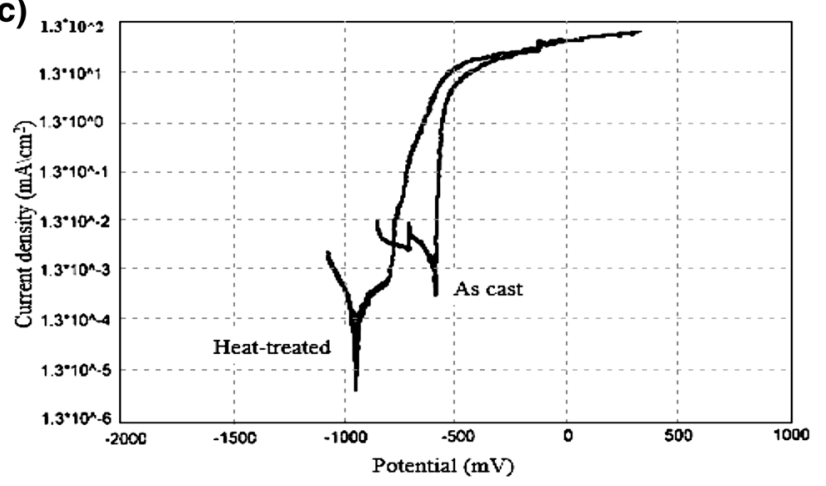

(d)

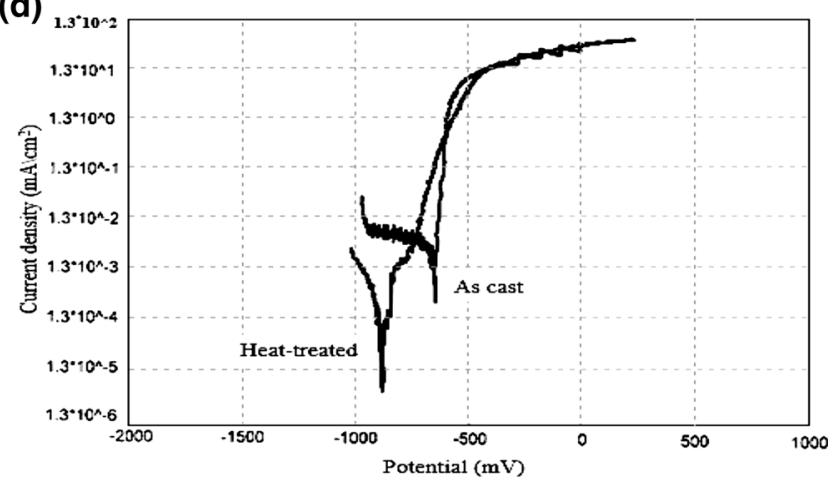

Fig. 8 Effect of heat treatment on the corrosion rate of $\mathrm{Al}-\mathrm{Si}$ alloy matrix composites with a $0 \% \mathrm{Al}_{2} \mathrm{O}_{3}, \mathbf{b} 15 \% \mathrm{Al}_{2} \mathrm{O}_{3}, \mathbf{c} 20 \% \mathrm{Al}_{2} \mathrm{O}_{3}$, and d $25 \% \mathrm{Al}_{2} \mathrm{O}_{3}$ 
reached that measured for the matrix alloy. The highest corrosion rate was recorded for MMC with $25 \mathrm{wt} \% \mathrm{Al}_{2} \mathrm{O}_{3}$ $(0.048 \mathrm{~mm} /$ year $)$. On the other hand, the corrosion resistance of Al-Si alloy as well as MMCs recorded noticeable improvements after heat treatment as shown in Fig. 8. The corrosion rate of $\mathrm{Al}-\mathrm{Si}$ alloy was $0.0216 \mathrm{~mm} / \mathrm{year}$ before heat treatment, while it was $0.002 \mathrm{~mm} / \mathrm{year}$ after heat treatment with corrosion resistance improving ratio of $90 \%$. The MMC with $25 \mathrm{wt} \% \mathrm{Al}_{2} \mathrm{O}_{3}$ showed poor corrosion resistance $(0.048 \mathrm{~mm} /$ year $)$ before heat treatment, but after heat treatment the corrosion resistance was improved
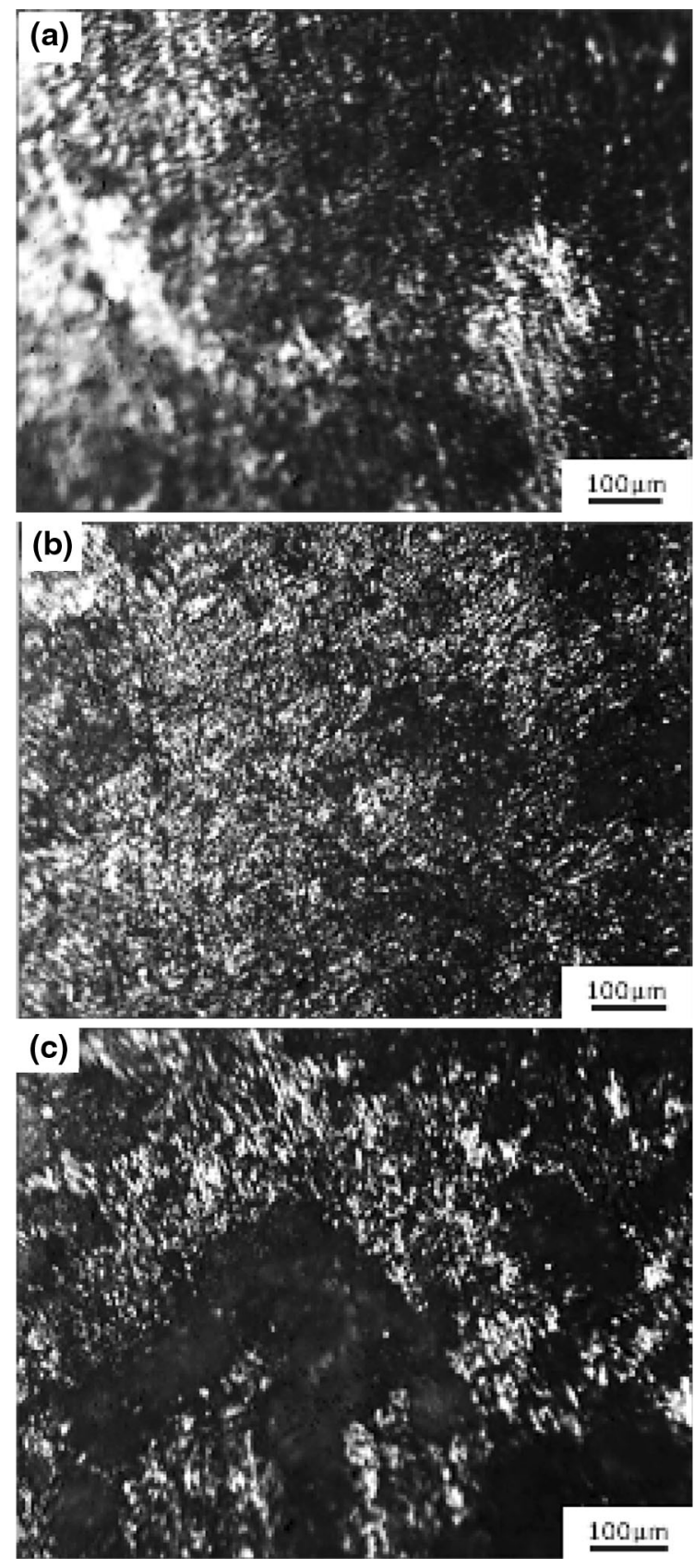

by $97 \%$. The enhancement in the corrosion resistance may be attributed to the improved dispersion of $\mathrm{Al}_{2} \mathrm{O}_{3}$ particles in the matrix allo, and the buildup of protective layers of aluminum hydroxide $\left(\mathrm{AlOH}_{3}\right)$, bayerite $\left(\mathrm{Al}_{2} \mathrm{O}_{3} \cdot 3 \mathrm{H}_{2} \mathrm{O}\right)$, and boehmite $\left(\mathrm{Al}_{2} \mathrm{O}_{3} \cdot \mathrm{H}_{2} \mathrm{O}\right)[34,35]$.

\subsubsection{Microstructure Examination After Corrosion Tests}

Figure 9 shows corroded surface after potentiodynamic test of MMCs and its matrix alloy before and after heat treatment. It is clear that MMCs as well as the matrix alloy were
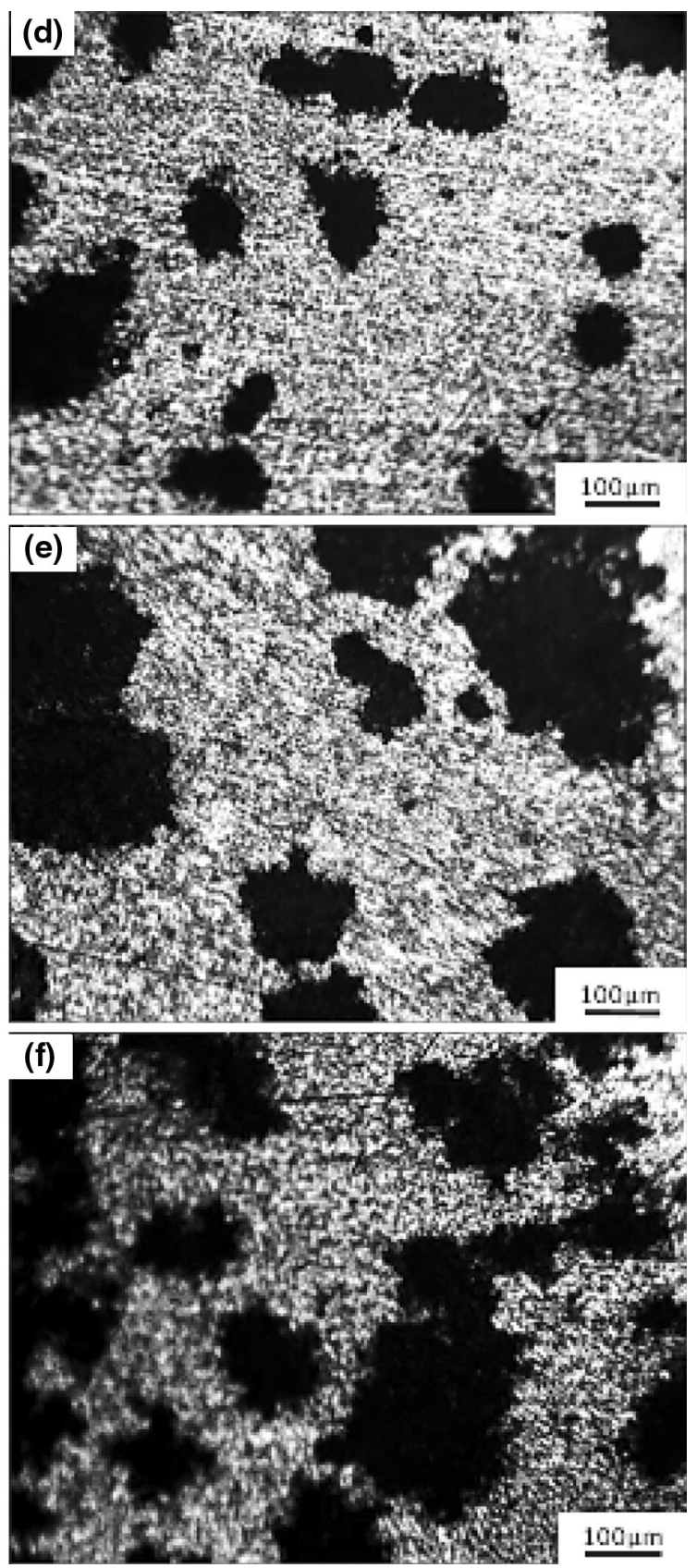

Fig. 9 Optical micrographs show the corroded surface of Al-Si alloy matrix and composites with 20 and $25 \% \mathrm{Al}_{2} \mathrm{O}_{3}$ after potentiodynamic corrosion tests; $\mathbf{a}-\mathbf{c}$ before heat treatment and $\mathbf{d}-\mathbf{f}$ after heat treatment 


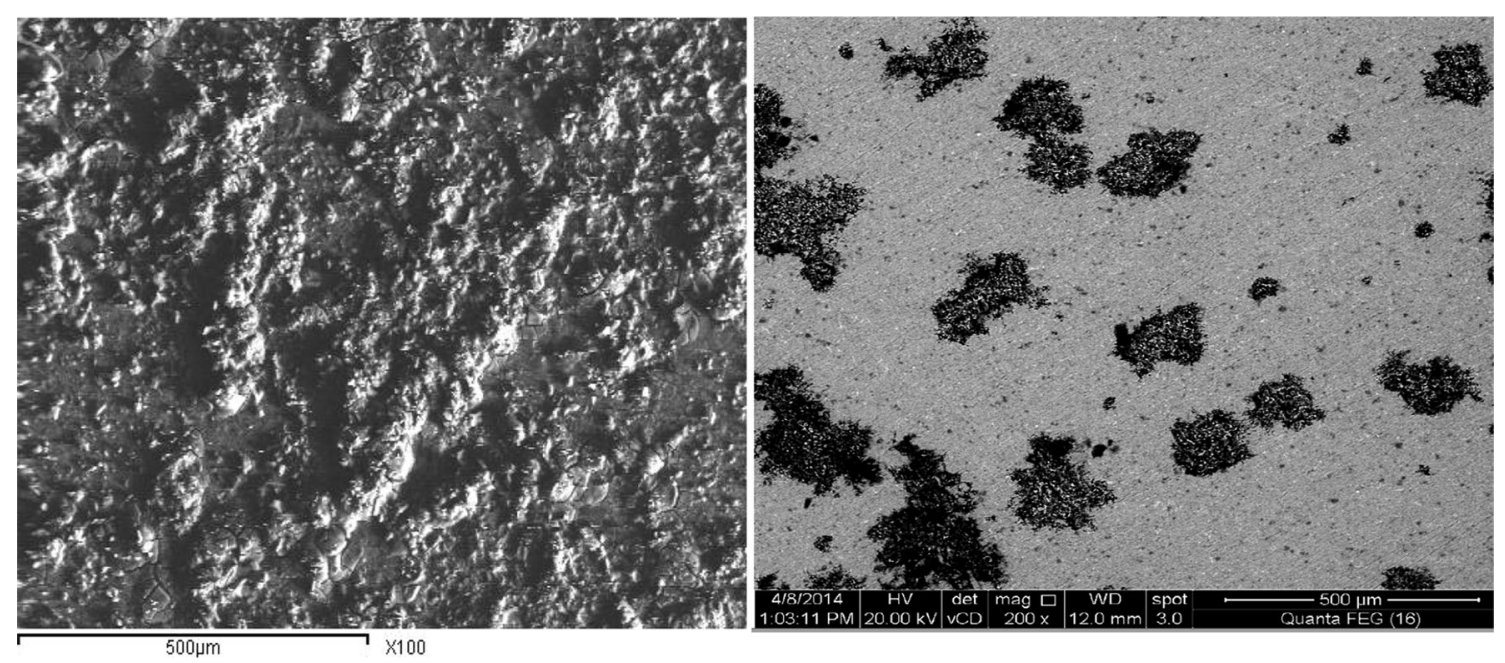

Fig. 10 SEM micrographs show the corroded surface of $\mathrm{MMC}$ with $25 \% \mathrm{Al}_{2} \mathrm{O}_{3}$ after potentiodynamic corrosion tests; $\mathbf{a}$ before heat treatment and $\mathbf{b}$ after heat treatment

attacked by pitting corrosion. Figure 9a shows high pits intensity. These pits seem to be enlarged in size. In Fig. 9b, the pits in MMC with $20 \mathrm{wt} \% \mathrm{Al}_{2} \mathrm{O}_{3}$ appear to be fine. Furthermore, it is obvious that the MMC with $25 \mathrm{wt} \%$ $\mathrm{Al}_{2} \mathrm{O}_{3}$ is subjected to worse corrosion by comparing Fig. 9c with Fig. 9b, where severe attack was very clear. However, these pits disappeared after heat treatment (Fig. 9d-f). Figure 10 confirmed that the heat treatment strikingly eliminated extensive pitting. These findings agree with the results obtained from the polarization curves.

\section{Conclusions}

The present study provides insights into the wear and corrosion behavior of the $\mathrm{Al}-\mathrm{Si}$ alloy matrix composites reinforced with different weight fractions of $\mathrm{Al}_{2} \mathrm{O}_{3}$ particles up to $25 \mathrm{wt} \%$. The main conclusions drawn from this study are as follows:

1. Microstructural examinations revealed the uniform distribution of $\mathrm{Al}_{2} \mathrm{O}_{3}$ particles in the $\mathrm{Al}-\mathrm{Si}$ matrix alloy.

2. The incorporation of $\mathrm{Al}_{2} \mathrm{O}_{3}$ particles up to $25 \mathrm{wt} \%$ led to marked improvements in the wear resistance of the Al-Si alloy.

3. The corrosion resistance of the matrix alloy was enhanced by adding $\mathrm{Al}_{2} \mathrm{O}_{3}$ particles up to $20 \mathrm{wt} \%$. However it was deteriorated by adding $25 \% \mathrm{Al}_{2} \mathrm{O}_{3}$.

4. The Al-Si alloy matrix composite with $10 \mathrm{wt} \% \mathrm{Al}_{2} \mathrm{O}_{3}$ has high corrosion resistance $(\sim 100 \mathrm{mV}$ passive range) with the corrosion rates of 0.86 and
$0.0051 \mathrm{~mm} /$ year after immersion and corrosion test at $600 \mathrm{rpm}$, respectively.

5. The heat treatment of the composites and matrix alloy resulted in relative improvements in both corrosion and wear resistance. These improvements were more pronounced in the case of corrosion at $600 \mathrm{rpm}$.

\section{References}

1. Tahamtan S, Halvaee A, Emamy M, Zabihi MS (2013) Fabrication of $\mathrm{Al} / \mathrm{A} 206-\mathrm{Al}_{2} \mathrm{O}_{3}$ nano/micro composite by combining ball milling and stir casting technology. Mater Des 49:347

2. Pacheco T, Nayeb-Hashemi H, Sallam HEM (1997) A comparison of two Nextel 440 Fibre reinforced aluminium composites using acoustic emission. J Mater Sci 32:3135-3142

3. Pacheco T, Nayeb-Hashemi H, Sallam HEM (1998) The effects of matrix and fiber properties on the mechanical behavior and acoustic emission in continuous fiber reinforced metal matrix composites. Mater Sci Eng A 247:88-96

4. Rao RN, Das S (2011) Effect of sliding distance on the wear and friction behavior of as cast and Heat-treated $\mathrm{Al}-\mathrm{SiCp}$ composites. Mater Des 32:3051

5. Rohatgi PK, Asthana R, Das S (1986) Solidification, structures and properties of cast metal ceramic particle composites. Int Met Rev 31:115

6. Walker JC, Rainforth WM, Jones H (2006) Lubricated sliding wear behavior of aluminum alloy composites. Wear 259:577

7. Bharath V, Madev N, Auradib V, Koric SA (2014) Preparation of $6061 \mathrm{Al}-\mathrm{Al}_{2} \mathrm{O}_{3}$ MMC's by stir casting and evaluation of mechanical and wear properties. In: 3rd international conference on materials processing and characterization (ICMPC 2014)

8. Vencl Aleksandar, Bobic Llija, Milan (2008) Microstructural and tribological properties of $\mathrm{A} 356 \mathrm{Al}-\mathrm{Si}$ alloy reinforced with $\mathrm{Al}_{2} \mathrm{O}_{3}$ particles. Tribol Lett 32:159

9. Das S, Prasad SV, Ramachandran TR (1989) Microstructure and wear of cast (Al-Si alloy) — graphite composites. Wear 133:173

10. Li XY, Tandon KN (1997) Subsurface microstructures generated by dry sliding wear on as-cast and heat treated Al metal matrix composites. Wear 203-204:703 
11. Pardo A, Merino MC, Merino S, Viejo F (2005) Influence of reinforcement proportion and matrix composition on pitting corrosion behaviour of cast aluminium matrix composites (A3xx.X/Sicp). Corros Sci 47:1750

12. Berkeley DW, Sallam HEM, Nayeb-Hashemi H (1998) The effect of $\mathrm{pH}$ on the mechanism of corrosion and stress corrosion and degradation of mechanical properties of AA6061 and Nextel 440 fiber reinforced AA6061 composite. Corros Sci 40:141

13. Winkler S, Flower H (2004) Stress corrosion cracking of cast 7XXX aluminium fibre reinforced composites. Corros Sci 46:903

14. Bobic B, Mitrovic S, Babic M, Bobic I (2009) Corrosion of aluminium and zinc-aluminium alloys based metal-matrix composites. Tribol Ind 31:44

15. Toptan F, Alves AC, Kerti I, Ariza E, Rocha LA (2013) Corrosion and tribocorrosion behavior of $\mathrm{Al}-\mathrm{Si}-\mathrm{Cu}-\mathrm{Mg}$ alloy and its composites reinforced with $\mathrm{B} 4 \mathrm{C}$ particles in $0.05 \mathrm{M} \mathrm{NaCl}$ solution. Wear 306:27

16. Kolman DG, Butt DP (1997) Corrosion behavior of a novel SiC/ $\mathrm{Al}_{2} \mathrm{O}_{3} / \mathrm{Al}$ composite exposed to chloride environments. J Electrochem Soc 144:3785

17. Sun HH, Chen D, Li XF, Ma NH, Wang HW (2009) Electrochemical corrosion behavior of Al-Si alloy composites reinforced with in situ Tib2 particulate. Mater Corros 60:419

18. Włodarczyk-Fligier A, Dobrzanski LA, Adamiak M (2007) Influence of heat treatment on corrosion resistance of PM composite materials. J Achiev Mater Manuf Eng 24:127

19. Saber D, Abdel-Karim R, Abd El-Aziz Kh, Kandel AA, Sallam HEM (2014) Tribocorrosion behavior of Al-Si matrix composite reinforced with alumin. J Bio-Tribo-Corros

20. Daoud A, Reif W (2002) Influence of $\mathrm{Al}_{2} \mathrm{O}_{3}$ particulate on the aging response of A356 Al-based composites. J Mater Process Technol 123:313

21. Yilmaza O, Buytozb S (2001) Abrasive wear Of $\mathrm{Al}_{2} \mathrm{O}_{3}$-reinforced aluminium-based MMCs. Compos Sci Technol 61:2381

22. Nunes PCR, Ramanathan LV (1995) Corrosion behavior of alumina-aluminum and silicon carbide-aluminum metal matrix composites. Corrosion 51:610

23. Al-Qutub AM (2006) Effect of sub-micron $\mathrm{Al}_{2} \mathrm{O}_{3}$ concentration on dry wear properties of 6061 aluminium based composite. J Mater Process Technol 172:327

24. Kok M (2005) Production and mechanical properties of $\mathrm{Al}_{2} \mathrm{O}_{3}$ particle-reinforced 2024 aluminium alloy composites. J Mater Process Technol 161:381
25. Kala H, Mer KKS, Kumar S (2014) A review on mechanical and tribological behaviors of stir cast aluminum matrix composites. Procedia Mater Sci 6:1951-1960

26. Ramachandra M, Radhakrishna K (2007) Effect of reinforcement of flyash on sliding wear, slurry erosive wear and corrosive behavior of aluminium matrix composite. Wear 262:1450

27. Karakulak Erdem, Zeren Muzaffer, Yamanoğl Ridvan (2013) Effect of heat treatment conditions on microstructure and wear behaviour of $\mathrm{A} 14 \mathrm{Cu} 2 \mathrm{Ni} 2 \mathrm{Mg}$ alloy. Trans Nonferrous Met Soc China 23:1898

28. Chen Rong, Iwabuchi Akira, Tomoharu Shimizu (2000) The effect of a T6 heat treatment on the fretting wear of a SiC particle-reinforced A356 aluminum alloy matrix composite. Wear 238:110

29. Lashgari HR, Zangeneh Sh, Shahmir H, Saghafi M, Emamy M (2010) Heat treatment effect on the microstructure, tensile properties and dry Sliding wear behavior Of A356-10\% $\mathrm{B}_{4} \mathrm{C}$ cast composites. Mater Des 31:4414

30. Sameezadeh M, Emamy M, Farhangi H (2011) Effects of particulate reinforcement and heat treatment on the hardness and wear properties of AA 2024-MOSi 2 nanocomposites. Mater Des 32:2157

31. Dobrzanski LA, Włodarczyk A, Adamiak M (2005) Structure, properties and corrosion resistance of pm composite materials based on EN AW-2124 aluminum alloy reinforced with the $\mathrm{Al}_{2} \mathrm{O}_{3}$ ceramic particles. J Mater Process Technol 162-163:27

32. Das S, Saraswathi YL, Mondal DP (2006) Erosive-corrosive wear of aluminum alloy composites: influence of slurry composition and speed. Wear 261:180

33. Shimizu Yoshiaki, Nishimura Toshiyasu, Matsushima Iwao (1995) Corrosion resistance of Al-based metal matrix composites. Mater Sci Eng A 198:113

34. Ahmad Z, Abdul Aleem BJ (2002) Degradation of aluminum metal matrix composites in salt water and its control. Mater Des 23:173

35. Alaneme KK, Bodunrin MO (2011) Corrosion behavior of alumina reinforced aluminium (6063) metal matrix composites. J Miner Mater Charact Eng 10:1153 